\title{
Discharge Indicator
}

National Cancer Institute

\section{Source}

National Cancer Institute. Discharge Indicator. NCI Thesaurus. Code C154888.

An indication as to whether there is the presence of discharge. 